\title{
Intolerance Acts in Philippines and Indonesia: a Comparative Study
}

\author{
Clara Ignatia Tobing ${ }^{1 *}$ and Nestor C. Nabe ${ }^{2}$ \\ ${ }^{1}$ Bhayangkara Jakarta Raya University, 17121, Bekasi, Indonesia. \\ ${ }^{2}$ University of Mindanao, 8021, Davao City, Philippines
}

\begin{abstract}
This study compares the existence of intolerance acts in Philippines and Indonesia. This study is a qualitative type of research which involves in-depth interview and focus group discussion with the study informants. The informants consist of law enforcement agencies, nongovernment organizations, and religious groups from Philippines and Indonesia. The result reveals that understanding and application of intolerance acts in the Philippines and Indonesia are different. Unlike the Philippines, there are laws in Indonesia defining specific acts of religious intolerance. The acts of religious intolerance are widespread in Indonesia compared to the Philippines.
\end{abstract}

\section{Introduction and Literature Review}

Nowadays Indonesia is facing a challenge in defending religious diversity. It has a rapidly growing number of religious intolerance act. In 8 December 2016 there were 182 documentations of violation on religious freedom. In late 2015 until December 31 st, there were 197 events[1]. In 2016 religious based criminalisation and religious perverted became a national trend which also affected other form on intolerance act, and even turned into violence act with massive victims[2]. Government was blamed for accommodating regulation which also intimidated minorities, while a study showed 159 acts or $50,5 \%$ intolerance cases on 2016 was done by government actors [2].

The rising number of religious intolerance number is a result of poor law enforcement[3]. As a result of unclear regulation, there are several disharmonies on legal system occurred. Law enforcement failed to understand the main reason behind intolerance movement in Indonesia. Indonesian police officers also failed to act against hard-line groups and individuals that have continued to promote intolerance and spread hatred[4].

Philippines, on the other hands, follows the American model of church-state separation, thus the clear separation of church as the predominant religious institute and state institution prohibits the state from interfering in church matters, and prohibits the state from having a state religion[5]. This distinction plays major role on Philippine diversity and the neutral position of government official towards religious affiliation of its people also help the society moulding their view on diversity[5].

* Corresponding author: clara.tobing@ubharajaya.ac.id 
However, Philippines also face Moros long conflict [6], Muslim community stereotyping as terrorist [7], and the sign of Islam-phobia in modern Philippines [8]. While the latter reappeared with Marawi Attack by alleged joint of Maute Group, Abu Sayyaf, and Bangsamoro Islamic Freedom fighters on May 2017 [9], Philippines also started to face prejudice of the terrorist-stereotyping and injustice.

Therefore, a joint research between Bhayangkara Jakarta Raya University, Indonesia, and University of Mindanao, Philippines is conducted on how intolerance act occurs and the reasons behind the action. The observation of intolerance actors, both victims and offenders will help and assist those who victimized by crime and prevent victimization in the future.

\subsection{Indonesian Religious Regulation}

Indonesia, as a member of United Nations, has ratified several international covenant and treaties as measures of human rights protection on its citizens, including the Universal Declaration of Human Rights (UDHR). As a signatory, Indonesia has an obligation to ensure that 'everyone has the right to freedom of thought, conscience, and religion; this right includes freedom to change his religion or belief, and freedom, either alone or in community with others and in public or private, to manifest his religion or belief in teaching, practice, worship, and observance'. (CCPR General Comment No. 22: Article 18).

Indonesian's view on religious freedom can be seen on article 29 (1) of the 1945 Constitution of the Republic of Indonesia. However, such freedom was restricted by Indonesian Law No 1/PNPS of 1965 which acknowledged only six official religion: Islam, Catholicism, Protestantism, Buddhism, Hinduism, and Confucianism. This law then raised two main problem, first: the law implied as if Indonesian government and regulation only protect that six religion, and lastly: religious clause on that law allow government to interfere with religious freedom activities, not only on social interaction but also on other faith and belief that seems different than six mainstream religions [10].

\section{Objective of the Study}

The purpose of this research is to compare intolerance acts in Philippines and Indonesia. It seeks the definition and categorization, studies the police reaction, and lastly compares regulation in both countries regarding the problems of intolerance acts.

\section{Methodology}

This study used the mixed qualitative type of research; literature review, and in-depth interview with the study-informants and focus group discussions, with two groups of informants in this study representing the Philippines and Indonesia. In collecting the needed data, the author interview-questioning technique was used to gather the responses of the informants. The authors prepared an interview guide or interview plan which served as the basis of data collection. The informants consisted of law enforcement agencies, nongovernment organizations, and religious groups of the both countries. In the Philippines, there were 11 informants involved, consisted of eight representatives from Muslim organizations based in Davao City namely; Inspired Young Optimists Guild/MSU-IYOG, Ateneo de Davao University/AdDU Muslim Law Students Organization, Ateneo de Davao University/AdDU SALAM, Philippines Muslim Students Association, University of Mindanao Muslim Association for Hegemony, and Interschool Muslim Organization. Also, there were three Chief Inspectors from the Philippine National Police and eight officers from Indonesian National Police who were included as informants. 


\section{Result and Discussion}

In this study, intolerance acts are limited only to incidences in which the primary motive or consideration in its commission was the religion or belief of the victim or the perpetrator. The findings in the study are presented in this section. The responses of the informants are grouped based on the guide questions.

\subsection{Familiarity with term "Intolerance" and Its Description}

The familiarity and understanding of the informants on the term "intolerance" are very important, considering that this is the basis for their inclusion in this study. In addition, this question elicited the perspectives of the informants from Philippines and Indonesia on the word "intolerance".

While the majority of the informants from Philippines claimed to be familiar with the term "intolerance" [11], on the other hands in Indonesia, intolerance is explained as a mass or group action that disrespects the culture and beliefs of others. It includes limiting other groups to have their basic rights such as freedom of religion which resulted in a greater gap or even clashes among those groups involved [12].

There is a similarity in the general definition and understanding of the term "intolerance" on both countries, however in Philippines, discrimination is the preferred term to describe the existence of such situation since religious intolerance is not common in Philippines.

\subsection{Acts of Intolerance Encountered by the Religious Organizations}

Wahid Institute and Setara Institute documented their 2016 report about many incidents of intolerance acts in Indonesia. These institutes categorized these acts as either Non-State Actor Violation indicating that the perpetrators are individuals or organizations and the State Actor Violation implying that the violator is the government [1][2]. In 2016, there were 110 victims considered as Non-State Actor Violation while 120 victims for State Actor Violation. In the Non-State Actor Violation, restriction/ban/termination of worship, hate speech and eviction are the top three violations. For State Actor Violation the top three acts are the following; misdirection of religion/faith, religious/faith based criminalization and activities restriction. Lastly, the report ended with a conclusion that both Non-State Actor Violation and State Actor Violation are committed to religion/faith as the main motive of these perpetrators [1][2].

In Philippines, there is no document from the interviewer on any complaints involving intolerance or discrimination. In some instances, the members might have felt discriminated but these acts did not result in the violation of laws or their rights. When an action or maybe a regulation will be applied to certain individuals by another person belonging to a different tribe, class or religion, those individuals may feel discriminated. More often, it's the perception that they are being discriminated [11].

\subsection{Organizational Responses to Acts of Intolerance}

This is a follow-up statement on whether the organizations represented by the informant encountered incidents involving intolerance acts. The acts aim at determining the actions of these organizations in response to acts of intolerance reported to them.

One of the respondents claimed to have a personal response. He said, "If I happen to face discrimination, I will expose the case on social media first, since people are afraid their malicious action gets exposed to the public. If the action threatens my life, of course, I will take the case to the police office, but since it will take a long time to the police officer to 
investigate the cases, it will not be my first option. Better to expose that to social media, since a lot of people will help me quickly"[13].

In Indonesia, the organizations have many and different responses to the rampant acts of intolerance committed in their country[14]. The organizations in Philippines recorded no incidence of discrimination[11].

\subsection{Informants' View on the Social Conditions of Minorities in Philippines}

The assumption of the existence of intolerance can be explained by the informants' knowledge on the social conditions of minority groups, especially the tribes professing the religion of Islam. Through the limited data, the minority groups in Philippines especially those professing Islam as a religion live in communities with scarce economic and social opportunities [15].

\subsection{Informants' Description of Minority Groups in Philippines}

There is a big difference on how minorities are described in both countries based on the gathered data. In the Philippines, minorities are characterized by their distinct culture and tradition from the mainstream society [13]. The Indonesian description of minority limits to the non-adherence to Sunni Islam religion, anybody with religious beliefs outside of the Sunni (Islam Syiah, Islam Ahmadiah, Gafatar, Christian, Taoism, Hinduism, Confucianism, Buddhism, and other traditional beliefs) is considered as the minority [16].

\subsection{Police Officers' Experiences on Unlawful Case Based on Religious Acts}

In Philippines, all the three informants responded negatively when asked whether they had encountered unlawful cases based on religion [17]. This question aims at establishing the work related experiences of that they had encountered cases with religion as a motivation due their rank and service term in their own country [18].

This is contrary to the responses of the Indonesian police officers. Accordingly, all of them encountered incidents involving religious acts which are considered as unlawful. [14]

The difference on the experiences of police officers from the two countries may mean several things. First, there are no unlawful incidents in the Philippines committed against religion or it may be present but not reported to the police. It may also mean that because there are no national laws in the country defining such act, hence it cannot be acted by the police. This is contrary to the case of Indonesia because of the several incidents of religionbased violations encountered by the Indonesian police officers.

\subsection{Familiarity of the Police Officers with Statutes or Laws Criminalizing Acts of Intolerance}

In Philippines, aside from an obligation to have complete knowledge of laws police officers are mandated to investigate and establish the possible laws that are violated [18]. Since there are laws also in Indonesia concerning religious intolerance [19], the country's police officers should be familiar with these laws.

When asked whether they are familiar with any laws or statutes defining or penalizing religious intolerance in the Philippines, they responded on the contrary [17]. On the other hand, Indonesian police officers declared familiarity of all the laws criminalizing acts of intolerance in Indonesia [14]. 
While Indonesian police officers are familiar with their laws criminalizing acts of religious intolerance, the claim of police officers in the Philippines to have no knowledge of such laws is actually based on their non-existence. Although under Article III of the Philippine 1986 Constitution, it provided the freedom of religion as part of the Bill of Rights, there is yet an enabling law specifically criminalizing acts committed against religious intolerance. There are only laws prohibiting discrimination against women, sexual orientation, and even age [20].

As a consequence, there are laws present in Indonesia defining acts against religious intolerance while it is absent in the Philippines, at least at the national level.

\subsection{Police Officers to Enumerate Laws Criminalizing Acts of Intolerance}

All of the questioned police officers in Philippines provided a negative answer, when they unanimously claimed that they do not have knowledge of such laws [17]. However, because there are laws in Indonesia criminalizing acts of intolerance, the police personnel were able to enumerate two; sanction for intolerance acts under the Criminal Code of Indonesia under Law Number 40.2008 and Law Number 1 /PNPS/1965 or known as Blasphemy Law [14].

\subsection{Informants' Insight on the Relevance of "Intolerance" with the Recent Situation in the Philippines}

Most of the informants indicated that "intolerance" is not relevant to the recent situation in Philippines [11]. "I do not think the term intolerance is relevant in the Philippine setting. Muslims can freely act or perform their religious duties," said an informant [21].

Although one finds it is relevant in the Philippine context because "intolerance" "is now a global issue" since Maute terrorist siege in Marawi city on last 2017. She further stated the following: "...we suffer the prejudice of the society towards us. The challenge is not really in convincing these people who are destroying our city but to let people know that we also are victims. It seems that no matter how hard we try to show the people that Muslims are peace-loving people, there are also those who will stain our reputation" [13].

All the Indonesian informants claimed that the recent situation in Philippines has relevance to intolerance, albeit they failed to explain how [14]. This is in contrast with how the Philippine informants view the situation. To them, the atrocities committed by the ISISinspired Maute Terrorist group cannot be attributed to religion. There might be instances of religious discrimination in the country, either perceive or real, but these do not lead to acts of terrorism. [11] Although the Maute terrorist group makes it appear that it is fighting in defense of the Islamic religion, the majority of the Filipino Muslims and Christians alike do support it. [23]

\subsection{Informants' Suggestion in Achieving Diversity Harmonization}

The respondents in Philippines are all in agreement that there should be unity despite differences in religion and tribal affiliations, especially among Muslims and Christians. Among the notable suggestions to understanding between these groups are the following; history education to include the history of the Moro and the Mindanao Island as a whole to the basic education years of the Philippine education system [13], education and harmonization, and the youth and children exposure to meet and the first-hand experience to talk with people from different culture [15], laws, rules, and regulation reinforcement in criminalizing and acknowledging issues involving discrimination [18], and government and the congress full recognition to the historical injustices to the Moros [21] [23]. 
The source of information from Indonesia suggested that education of history and interfaith study are the key to achieving unity despite diversity. Additionally, other informants recommend respecting each other despite the diversity, "because Indonesia is different but one" [11].

There is a common suggestion emanating from both countries that would lead to harmony. It seems the key to ensuring agreement among individuals despite the existence of differences in political, ideological, and spiritual beliefs is education. The right education will result in understanding and appreciation of the diverse cultures outside one's own.

\section{Conclusion}

This study was able to compare the existence of intolerance acts in the Philippines and Indonesia. The result revealed that understanding and application of intolerance acts in both countries are different. Unlike the Philippines, there are laws in Indonesia defining specific acts of religious intolerance and enforced by the country's police agency, but acts of religious intolerance are more visible in Indonesia compared to the Philippines.

\section{References}

1. Setara Institute, Indeks Kerja HAM (Jakarta, 2016)

2. Wahid Foundation, Ringkasan Eksekutif Laporan Tahunan Kebebasan Beragama dan Berkeyakinan di Indonesia tahun 2016 (2016)

3. A. Suaedy, Kebebasan Beragama dalam Konstitusi dan Perundangan-undangan di Indonesia (Wahid Institute, Jakarta, 2016)

4. F. Sidiq, Police Admit Law Enforcement Against Intolerant Groups Weak (The Jakarta Post, Jakarta, 2017)

5. R. C. Pangalangan, Religion and the Secular State: National Report for the Philippines (International Center for Law and Religion Studies, Utah, 2010)

6. S. Jubair, Bangsamoro-A Nation Under Endless Tyranny (IQ Marin SDN BHD, Malaysia, 1999)

7. S.A. Gutoc, Causes of "Terrorism": The Philippine Case (Arellano Law and Policy Review, 2003)

8. A Mawalil, The Muslim Type (The Rappler, 2015)

9. M. Betteridge-Moes, What happened in Marawi? (Al-Jazeera, 2017)

10. N. Hosen, Journal of Southeast Asian Studies 36, 3, Pp. 419-440 (2015)

11. This interview was conducted by one of the authors - Clara Ignatia Tobing - at several places in Davao City, Philippines from May - July 2017

12. A.J.Fenton, jiis 10, 2, Pp. 181-212 (2010)

13. This interview was conducted by one of the authors - Clara Ignatia Tobing - at Abreeza Mall, Davao City, Philippines at 14 May 2017

14. This online interview was conducted by one of the authors - Clara Ignatia Tobing - with 8 Indonesian Police Officer in Jakarta, Indonesia, at June 2017

15. This interview was conducted by one of the authors - Clara Ignatia Tobing - at Atteneo de Davao University, Davao City, Philippines at 20 May 2017

16. N. Puspitasari, The Increasing Intolerance Towards Religious Minorities in Indonesia: Have the Existing Laws Been Protecting or Marginalising Them? (Tilburg, 2015)

17. This focus group discussion was conducted by one of the authors - Nestor C. Nabe - at Post Graduate School, University of Mindanao Davao City, Philippines at 4 June 2017 
18. Philippine National Police Operation Manual, Philippine National Police Operational Procedures (Philippines, 2010)

19. S.Arifin, Attitudes to Human Rights and Freedom of Religion or Belief In Indonesia (Penerbit Kanisius, Yogjakarta, 2010)

20. C.S.R. Austria, Reproductive Health Matter 12, 24, Pp. 96-103 (2004)

21. This interview was conducted by one of the authors - Clara Ignatia Tobing - at Atteneo de Davao University, Davao City, Philippines at 5 June 2017

22. A. L. Strachan, Conflict analysis of Muslim Mindanao (Rapid Literature Review, Birmingham,2015)

23. This focus group discussion was conducted by one of the authors - Clara Ignatia Tobing - with Philippines Muslim Students Association, Atteneo de Davao University, Davao City, Philippines at 7 June 2017 